\title{
Impact of Foreign Direct Investment on Industrial Growth of India
}

\author{
Muthusamy, S. Sundararajan
}

\begin{abstract}
In India the Foreign direct investment (FDI) has received a staged improvement from instigate of the Make in India scheme, according to recent survey. There was a incredible increase in FDI inflows (40\%) particularly in manufacturing sector from October, 2014 to June, 2019. The industrial sector is considered to be the one of the dominant sectors that contribute the major Indian GDP. India has been ranked fourteenth in the factory output in the world. This was because of the launch of initiative, which sought for promoting manufacturing segments and be a magnet for foreign investments. More than 56 manufacturing units are benefitted in the entire globe. In the recent times during the year 2014 to 2019 the Industrial production inclined to 3.1 per cent, mainly on account of improvement and to encourage talent augmentation towards the various sectors of the economy. This article brings out the recent efforts taken by the government for encouraging the FDI into various sectors and how it has made a pathway. In the last ten years India has shown a tremendous increase in Foreign Direct Investment into the various sectors in economy. Even though Government of India has make a pathway for attracting FDI on various sectors, this papers focuses on explaining the impact of make in India scheme on FDI. In this paper period of five years has been considered for the analysis. The Statistical Tools like Karl Pearson's Coefficient Correlation and One - Way ANOVA has been used for the analysis of data. To study the relationship between the FDI and IIP correlation is used for the analysis of data.
\end{abstract}

Keywords : GDP, FDI, Make in India Scheme, Industrial Growth, Manufacturing units.

\section{INTRODUCTION}

It has long been discussed that Foreign Direct Investment (FDI) plays an significant role in promoting export and for the transformation of Indian economy. Foreign Direct Investment (FDI) is well thought-out as an imperative means of promoting export of the multitude countries. Foreign direct investment (FDI) in India has conventional enhancement from initiate of the Make in India scheme, from October, 2014 to June 2018 there was a tremendous increase in FDI inflows. Most of the manufacturing units were the magnets for attracting the FDI. Already the concept of Make in India has succeeded and some of the products the domestic market is focusing the increasing in demand. The employment opportunities are generated in ample numbers across the various sectors in India. By the means of increasing the productivity and productive capacity, it is argued that the FDI

Revised Manuscript Received on September 25, 2019

Dr.A.Muthusamy, Professor, Department of International Business, Alagappa University, Karaikudi-04, Tamilnadu, India

Mr. S. Sundararajan, Ph.D. Research Scholar, Department of International Business, Alagappa University, Karaikudi-04, Tamilnadu, India exercises the exports and the transfer of technology also matters for the upgrading of local workforce training. The make in India initiative has given the way and opportunity for the host countries to export by make easy admittance to the new and great foreign markets. Since eighties, India has witnessed the tremendous increase in the flow of FDI and particularly from 1990's for the liberalization of the Indian economy.

Around 56 manufacturing units are being operated by the private players to encourage more FDI and it is witnessed that above $90 \%$ of the FDI. The make in India scheme has made a state - wise analysis of FDI inflows by the economic survey and it has been witnessed that, Haryana, Delhi, Karnataka, Gujarat, Tamil Nadu and Andhra Pradesh has attracted beyond $70 \%$ of total FDI inflows to India during the last decade. Indian government has made ranking among the top 10 striking destinations for diversified investments. It has become investor friendly in terms of foreign investments. Government of India took some effective steps and the modifications in the FDI policy are done to ease up the businesses and for gearing up the FDI in the upcoming years. Nowadays, FDI has become an instrument of international economic integration. India is said to be the second being the second most populous country, consumer spending grew from US\$ 549 million to 1.06 trillion between 2006 and 2011 . This, places India as one of the world's largest consumer market by 2015 . India's consumption is expected grow annually over next 20 years. The growing upper middle class population in the country' places India as a 'consumption hub' in the world. The rise in India's middle class is very significant in augmenting establishment of production capacities in terms of consumption (i.e. Made for India).

\section{NEED FOR THE STUDY}

Good number of researches have been carried out in this study but this study encompasses of the facts that show that the make in India concept has an impact on FDI inflows. The population is increasing at the binomial rate and the production units are focusing on serving the population with the goods and services. This study will analyze the attraction of FDI to various production units and how they are productive. For this study the researcher has used compound annual growth rate for analyzing the rate of growth each year. The make in India initiative has given a way for the FDI and many sectors have been identified under the schema. Researcher has selected last six years for the analysis and there are certain diminutive sectors where the FDI is prohibited. During the year 2015, government has brought FDI related regulations and the liberalization of various sectors.

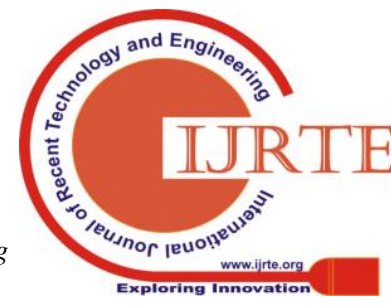


MIIM (Make in India Mittelstand) is only meant for attracting more number of foreign companies, and it's a smooth process. Many intellectuals have focused from separate angles but an attempt is made to identify the effectiveness of make in India initiative.

\section{THE OBJECTIVE OF THE STUDY}

1) To analyze the Trend of Industrial growth rate in India.

2) To examine the trend of FDI inflow in Manufacturing sector.

\section{RESEARCH METHODOLOGY}

In this research article, researcher has used secondary data for this study. The data collected from various sources such as official portal of make in India, DIPP, EXIM bank and other relevant journals. This study is on the basis of theoretical framework of consolidated FDI policy, ministry of commerce, Government of India. In this study, Comprehensive analysis, reasons for selecting India as a hub in manufacturing and the correlation between FDI and IIP (Index of Industrial Production).

Sources of Information: The statistical data was collected using the secondary sources, the published and unpublished data were collected from various forms like journals, agencies and government organizations.

Statistical Tools and Techniques: In this study, some of the statistical tools like Karl Pearson's Coefficient Correlation and One - Way ANOVA has been used for the analysis.

\section{PERIOD OF THE STUDY}

This study has been conducted for the period of five years from 2013 - 2014 to 2018 -2019. Researcher has gathered the secondary data for the analyzing the FDI inflows into the selected sectors in India.

\section{REVIEW OF LITERATURE}

The review of literature has been collected on the basis of past studies conducted on this domain.

Prasad, et. al. (2007) ${ }^{\mathbf{1}}$, in their article, they have investigated the results which permit the FDI and foreign collaboration. The foreign investment mostly attracts the manufacturing sector and the services industry, since inception. Their study also analyzed the sectors on which the government has imposed the restrictions such as agriculture, real estate, railway transport, etc. Some of the sectors in the economy are still supported by the government and are availing the foreign investments.

Dunning, Lundan $\mathbf{( 2 0 0 8}^{\mathbf{2}}$, in their article it was highlighted that there is a spillover effect emerges the linkage between the FDI and the host country economic agents. The FDI has generated the industrial growth in the aspect of more investment in the emerging sector.

Narayana $(\mathbf{2 0 1 3})^{3}$, in his research article that more number of foreign direct investment is being attracted by the key policy makers. The foreign direct inflows has been attracted in large quantum and some of the basic constraints in general and the foreign direct investment.

Singh, Gupta $(\mathbf{2 0 1 3})^{4}$, in their study they discussed about the India's foreign capital policy and it was concluded that the policy framework in India has changed from various challenges affecting the Indian Foreign Trade policy from 1948 to 1966 and the selective restrictive policy 1967 to 1979. Only from 1991 the liberal investment climate has been created.

Lakshmana Rao, Ravikanth (2016) ${ }^{\mathbf{5}}$, in their studies it is observed that the major motive behind the objective is to focus on heavy industrial units, public enterprises, generating the employment, etc. It is stated that the overseas investing company may invest in any of the subsidiary or associate foreign country. The company may invest at divergent sectors for the acquisition of shares and the title.

\section{TREND OF INDUSTRIAL GROWTH}

According to the National Accounts Statistics reproduced by the Government of India in 2018 - 2019, the industrial growth was stood at $9.6 \%$, the below table represents the Trend of Industrial Growth.

Table 1:TREND OF INDUSTRIAL GROWTH

\begin{tabular}{|l|c|l|l|l|l|l|}
\hline SECTORS & $\begin{array}{l}\mathbf{2 0 1 3} \\
-\end{array}$ & $\begin{array}{l}\mathbf{2 0 1 4} \\
\mathbf{2 0 1 4}\end{array}$ & $\begin{array}{l}\mathbf{2 0 1 5} \\
\mathbf{2 0 1 5}\end{array}$ & $\begin{array}{l}\mathbf{2 0 1 6} \\
\mathbf{2 0 1 6}\end{array}$ & $\begin{array}{l}\mathbf{2 0 1 7} \\
\mathbf{2 0 1 7}\end{array}$ & $\begin{array}{l}\mathbf{2 0 1 8} \\
\mathbf{2 0 1 8}\end{array}$ \\
\hline Mining and Quarying & 5.13 & 5.32 & 5.47 & 6.12 & 6.17 & 7.25 \\
& & & & & & \\
\hline Automobile & 8.24 & 8.65 & 8.87 & 9.22 & 9.32 & 10.14 \\
\hline Chemicals & 2.47 & 3.12 & 3.78 & 4.27 & 4.32 & 5.14 \\
\hline Telecommunication & 6.3 & 6.57 & 6.84 & 7.84 & 7.89 & 8.33 \\
\hline
\end{tabular}

Source: Central Statistical Office, Government of India.

From the above Table 1, according to the NAS (National Accounts Statistics) which is circulated by Government of India, from 2013 - 2014 to 2018 - 2019, the growth in the Industrial Index was at $2.64 \%$ and $5.23 \%$ during the year 2016 - 2017 to 2018 - 2019. Among the Industries the Automobile and Telecommunication has shown the Growth at steady rate. This is very clear from the above Table 1 that the Index of Industrial Production (IIP) is getting recovered in slow nut with the average growth rate of $2.12 \%$.

\section{TREND OF INDUSTRIAL GROWTH RATE}

The Index of Industrial Production (IIP) is considered to be an indicators which shows the flow of FDI in industrial sector and it is a crucial measure to see the industrial output of country. FDI inflows into India and IIP of the corresponding period for the six years is represented in the below table to understand the relation.

Table 2:FDI and IIP FOR 2013 - 2019

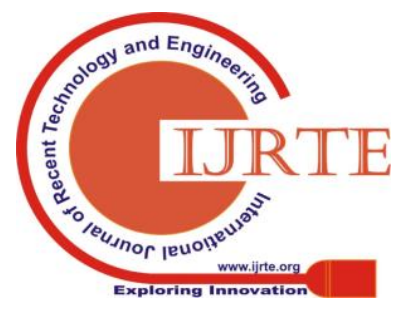




\begin{tabular}{|c|c|c|}
\hline YEAR & $\begin{array}{c}\text { TOTAL FDI } \\
\text { (in US \$ Million) }\end{array}$ & $\begin{array}{c}\text { INDEX OF INDUSTRIAL } \\
\text { PRODUCTION }\end{array}$ \\
\hline $2013-14$ & 36396.00 & 172.03 \\
\hline $2014-15$ & 37854.00 & 184.25 \\
\hline $2015-16$ & 38274.00 & 177.22 \\
\hline $2016-17$ & 37892.00 & 187.06 \\
\hline $2017-18$ & 39147.00 & 188.67 \\
\hline $2018-19$ & 39894.00 & 190.24 \\
\hline S.D & $\mathbf{1 2 0 2 . 4 9}$ & $\mathbf{7 . 1 6}$ \\
\hline CAGR & 1.54 & 1.69 \\
\hline
\end{tabular}

Source: DIPP Fact Sheet, updated up to march 2020

\section{INTERPRETATION}

During the Study period 2013 - 19, from the Table 2 explains that the India's Total FDI and Index of Industrial Production, has been increased from US \$ 36396.00 to US\$ 39894.00 for the past six years. During the year $2014-15$ and on this the total steel has reported at $0.08 \%$ growth for the year $2014-15$. The Coefficient of variation for the total exports was at 0.26 percent and the steel exports stood at 0.30 percent. The CAGR for the total FDI stood at $1.54 \%$ and the CAGR for Index of Industrial Production stood at $1.69 \%$. This shows the positive growth trend and the covariance of the above is 5820.01 .

During the study period 2014- 2019, the standard deviation for the Total FDI is 1202.09 and the Standard Deviation for the IIP is 7.16. The high value in the SD shows the stagnant growth in the FDI inflows. During the year 2018 -19 , the value of Total FDI was higher and it was US\$ 39894Millions and the IIP was also higher during the year 2018 - 19 and it was 7.16. The FDI inflow during 2014 - 2016 shown a fluctuating trend. The recovery in the Industrial index is seen in some of the major sectors that include Coal and mining. There is an immense progress seen in many of the sectors such as Automobile, Telecommunication and chemicals. In India the industrial production is highly fluctuating. As per the Industrial Index, the Industrial Production has been slow down to $2.98 \%$ each year. The Industrial Growth has achieved a steady growth due to the recovery in the mining industries and followed by manufacturing industries.

\section{KARL PEARSON'S CORRELATION}

\begin{tabular}{|ll|c|c|}
\hline & & $\begin{array}{c}\text { Total } \\
\text { FDI }\end{array}$ & $\begin{array}{c}\text { Index of } \\
\text { Industrial } \\
\text { Production }\end{array}$ \\
\hline Total FDI & Pearson & 1 & .265 \\
& Correlation \\
& Sig. (2-tailed) & & .483 \\
& $\mathrm{~N}$ & 6 & 6 \\
\hline $\begin{array}{l}\text { Index of } \\
\text { Industrial }\end{array}$ & Pearson & .226 & 1 \\
Production & Correlation & .414 & \\
& Sig. (2-tailed) & 6 & 6 \\
\hline
\end{tabular}

Source: SPSS, Computed.

Correlation Coefficient of +0.483 indicates that there is a weak correlation between FDI inflows and Index of Industrial Production (IIP). According to this study, there is a long term relation between FDI inflows and IIP. FDI inflow hastens the manufacturing sector and contributes towards growth of

industrial output of the country. The Indian Industry protection could not be measured with respect to the effective rates of protection, given the extensive use of nontariff barriers in Indian trade policy. The Index of Industrial Production (IIP) reveals that the Industrial sector has shown a slow growth but in a steady manner and recorded a but steady manner with a percentage of 12.22 growth in the manufacturing sector.

The correlation indicates the presence or absence of a relationship, not the nature of the relationship. Correlation is not causation. Correlation is performed to determine the significance and the Value $\mathrm{N}=6$, the value of correlation stood at 0.226 , Since, the value is much lesser than the relationship between the two variables are 'weak'. It is seen that the relationship between the variables are very weak (since nearer the value to zero the relationship is weak). The value of coefficient of determination is said to be 0.226 and 0.414 and the $\mathrm{N}=6$. The relationship between the total FDI inflows and IIP and the value of FDI inflows is said to be 0.226 and 0.414 where the relationship between FDI inflows and the IIP is weak.

\section{FOREIGN INVESTMENT IN INDIAN MANUFACTURING}

The below Table 3 represents the value of Total FDI and Foreign Investments in Manufacturing.

TABLE 3:FOREIGN INVESTMENT IN INDIAN MANUFACTURING

\begin{tabular}{|c|c|c|}
\hline YEAR & $\begin{array}{c}\text { TOTAL FDI } \\
\text { (in US \$ Million) }\end{array}$ & $\begin{array}{c}\text { FOREIGN INVESTMENT IN } \\
\text { MANUFACTURING (IN US \$ } \\
\text { MILLION) }\end{array}$ \\
\hline $2013-14$ & 36396.00 & 47.90 \\
\hline $2014-15$ & 37854.00 & 93.40 \\
\hline $2015-16$ & 38274.00 & 65.30 \\
\hline $2016-17$ & 37892.00 & 63.80 \\
\hline $2017-18$ & 39147.00 & 96.10 \\
\hline $2018-19$ & 39894.00 & 84.40 \\
\hline S.D & $\mathbf{1 2 0 2 . 4 9}$ & $\mathbf{1 9 . 1 1}$ \\
\hline CAGR & 1.54 & 9.90 \\
\hline
\end{tabular}

Source: DIPP, Computed.

\section{INTERPRETATION}

During the period of the study i.e. from 2013 - 2014 to 2018 - 2019, from the Table 2 it may be inferred that the Total FDI of FDI inflows has been increasing from US \$ 37854 Million from US \$ 36396 Million and the Foreign investment in Manufacturing could also seen inclining during the year 2014 - 2015, as it has inclined to US \$ 93.40 Million. The trend of Foreign investment in Manufacturing has been seen in fluctuating trend. The CAGR of Total FDI stood at $1.54 \%$ and the CAGR of Foreign investment in Manufacturing stood at $9.90 \%$, which has given a clear picture of positive trend during the period of the study. Total FDI was at higher during the year 2018 - 2019 and it was US\$ 39894 Million, and the highest Foreign Investment In Manufacturing was during the year 2017 - 2018 and it was US $\$ 96.10$ Million. 


\section{KARL PEARSON'S CORRELATION}

The below table brings the correlation between the two variables i.e. FDI and Manufacturing.

Upon the results the discussions have been done below.

$\mathbf{H}_{\mathbf{0}}$. There is a significant relationship between the value of FDI and IIP.

$\mathbf{H}_{\mathbf{1}}$. There is no significant relationship between the value of FDI and IIP.

\section{CORRELATION ANALYSIS}

Correlations

\begin{tabular}{|c|c|c|c|}
\hline & & FDI & MANUFACTURING \\
\hline \multirow[t]{5}{*}{ FDI } & $\begin{array}{l}\text { Pearson } \\
\text { Correlation }\end{array}$ & 1 & .706 \\
\hline & Sig. (2-tailed) & & .117 \\
\hline & $\begin{array}{l}\text { Sum of Squares } \\
\text { and } \\
\text { Cross-products }\end{array}$ & $\begin{array}{r}7229908.83 \\
3\end{array}$ & 81120.550 \\
\hline & Covariance & $\begin{array}{r}1445981.76 \\
7\end{array}$ & 16224.110 \\
\hline & $\mathrm{N}$ & 6 & 6 \\
\hline \multirow[t]{5}{*}{ Manufg } & $\begin{array}{l}\text { Pearson } \\
\text { Correlation }\end{array}$ & .706 & 1 \\
\hline & Sig. (2-tailed) & 117 & \\
\hline & $\begin{array}{l}\text { Sum of Squares } \\
\text { and } \\
\text { Cross-products }\end{array}$ & 81120.550 & 1825.935 \\
\hline & Covariance & 16224.110 & 365.187 \\
\hline & $\mathrm{N}$ & 6 & 6 \\
\hline
\end{tabular}

Source: SPSS, Computed.

Correlation Coefficient of +0.117 indicates that there is a weak correlation between FDI inflows and the manufacturing sector. According to this study, there is a long term relation between FDI inflows and manufacturing sector. FDI inflows hastens the manufacturing sector and contributes towards growth of industrial output of the country, since only few manufacturing Industry have shown a good index of Industrial production. The Indian Industry protection could not be measured with respect to the effective rates of production, given the extensive use of nontariff barriers in Indian trade policy. The Index of Industrial Production (IIP) reveals that the Industrial sector has shown a slow growth, but in a steady manner and recorded a but steady manner with a percentage of $9.90 \%$ growth in the manufacturing sector.

The correlation indicates the presence or absence of a relationship, not the nature of the relationship. Correlation is not causation. Correlation is performed to determine the significance and the Value $\mathrm{N}=6$, the value of correlation stood at 0.706 , Since, the value is much lesser than the relationship between the two variables are 'weak'. It is seen that the relationship between the variables are very weak (since nearer the value to zero the relationship is weak). The value of coefficient of determination is said to be 0.117 and 0.706 and the $\mathrm{N}=6$. The relationship between the total FDI inflows and IIP and the value of FDI inflows is said to be 365.187 and 0.286 where the relationship between FDI inflows and the IIP is weak.TRIAL

\section{GROWTH OF INDUSTRIAL INDEX}

The below Table 4 represents the Percentage Growth of Industrial Index from 2013 - 14 to 2018 - 19. Statistical Tools like One - Way ANOVA has been used to analyze the mean significance between the selected variables.

(in Percentage)

\begin{tabular}{|l|c|c|c|c|c|c|}
\hline Sectors & $\mathbf{2 0 1 3 - 1 4}$ & $\mathbf{2 0 1 4} \mathbf{- 1 5}$ & $\mathbf{2 0 1 5} \mathbf{- 1 6}$ & $\mathbf{2 0 1 6} \mathbf{- 1 7}$ & $\mathbf{2 0 1 7} \mathbf{- 1 8}$ & $\mathbf{2 0 1 8} \mathbf{- 1 9}$ \\
\hline Mining and Quarrying & -0.78 & 5.84 & 5.98 & 6.21 & 6.37 & 7.23 \\
\hline Manufacturing & 2.10 & 4.12 & 4.35 & 4.89 & 5.14 & 6.40 \\
\hline Electricity, Gas & 2.22 & 2.33 & 2.78 & 3.27 & 3.65 & 4.80 \\
\hline Industry & 2.17 & 2.56 & 2.68 & 3.87 & 4.25 & 4.95 \\
\hline Construction & 1.89 & 2.11 & 2.74 & 2.98 & 3.97 & 5.23 \\
\hline
\end{tabular}

Source: CSO, Government of India.

From the above Table 4 , it is inferred that base year from $2013-14$ to $2018-19$ by applying the methods in the statistical part, there are some changes in methodology, in the table the data are noted with respect to the Indian industrial sector. During the study period the changes in the industrial growth could be seen from the mining and quarrying i.e from $-0.78 \%$ in the year $2013-14$ to $7.23 \%$ during the year $2018-19$. There is a tremendous growth in the Industrial Growth. The manufacturing sector has also shown the steady increase in the growth from $2.10 \%$ to $6.40 \%$ during the year $2013-14$ to
2018 - 19. The manufacturing sector has proven the increase in the Industrial growth consistently.

\section{ONE - WAY ANOVA}

The One - Way ANOVA has been conducted to see the mean significance between the variables.

Data in the below tables provide the data for the calculation, for the $f$ and $p$ values in the calculation. 


\begin{tabular}{|c|c|c|c|c|}
\hline Source & SS & df & MS & \\
\hline $\begin{array}{l}\text { Between - } \\
\text { treatments }\end{array}$ & 19.314 & 4 & 4.8285 & \\
\hline $\begin{array}{l}\text { Within } \\
\text {-Treatments }\end{array}$ & 71.9705 & 25 & 2.8788 & $\begin{array}{l}\mathrm{f}= \\
1.67725\end{array}$ \\
\hline Total & 91.2875 & 29 & & \\
\hline
\end{tabular}

Source: Computed

The above results show that the f-ratio value is $\mathbf{0 . 6 7 7 2 5}$. The p-value is 0.186697. The result is not significant at $\mathrm{p}<0.05$. Hence it is concluded that there is no significant difference in the computed values for the year wise FDI inflows and the Industrial Growth during the study period 2013 - 2014 to 2018 - 2019. The Industrial growth has clearly shown that there is a tremendous increase of FDI inflows and more certainly it has encouraged the FDI.

\section{CONCLUSION}

This paper examines the inflow of Foreign capital in the form of FDI and how it affects the industrial growth in India from 2013 - 2014 to 2018 - 2019 by applying the statistical techniques. The period of the study is much crucial, since it is post recession era, and it is clear that India has attracted the FDI inflows in higher rate into the manufacturing sector. The results of the Karl Pearson's correlation has shown the results that the relationship between the FDI and the Industrial Growth has shown a positive trend among the consecutive years. The competitive investment climate in India has created the inflow of FDI into India, and the competitive climate is the basis for FDI to enter into the economy and for the growth of Industrial potential. For improving the industrial infrastructure and to raise the internal absorptive capacity there shall be different key policy measures. For the FDI to be the better inflow and to nurture with the economic growth, enriching the local entrepreneurship, stable macroeconomic conditions and to augment the procedure of development.

\section{REFERENCES}

1. http://www.makeinindia.com/foreign-direct-investment.

2. Prasad, et. al (2007), Foreign Direct Investments and the Legal Profession in India , Delhi Business Review X Vol. 8, No.1, JanuaryJune.

3. Dunning, Lundan (2008), Multinational Enterprises, 2nd Edition, Edward Elgar Publishing Limited, Pp. 2 -8.

4. Narayana (2013), Foreign Investment and Indian Economy (Ed), Manglam Publishers \& Distributors, Delhi, Pp. 26 - 27.

5. Singh, Gupta (2013), "Foreign Direct Investment and Industrial Development in India", Thesis submitted to Maharshi Dayanand University Rohtak for the degree of doctor of philosophy in Department of Commerce.

6. Lakshmana Rao, Ravikanth (2016), Make in India and Foreign Direct Investment (FDI) - synergetic effect on Economic Growth, SSRN Journal, September 2015, Pp. 1-8.
7. www.fipb.gov.in

8. Hand Book of Statistics on Indian Economy, Reserve of India, Various issues.

9. www.mospi.nic.in / India Manufacturing Barometer 2019, Building Export Competitiveness, FICCI, Jan 2019.

10. Agarwal J., Khan M.A (2011)., "Impact of FDI on GDP: A comparative study of China and India", International Journal of Business Management, Vol. 6, Issue - 10, 2011, pp. 71-79.

11. Index of Industrial Production, MOSPI, CSO, Government of India

12. Sharma, Khurana (2013), Role of FDI in Various Sectors, International Journal of Advances in Management and Economics, Vol. 4, Issue - 3 , 2013, Pp. 12 - 14.

13. Mahendra Sinha, Arindam, Partha (2018), Foreign Direct Investment and Indian Industries: A Dynamic Panel Study, International Journal of Pure and Applied Mathematics, Volume 118 Issue. 18, 2018,ISSN: 1279-1294, Pp. 1279 - 81. 